\title{
Casamentos indígenas, casamentos mistos e política na América portuguesa: amizade, negociação, capitulação e assimilação social
}

Vania Maria Losada Moreira ${ }^{1 *}$

${ }^{1}$ Universidade Federal Rural do Rio de Janeiro, Seropédica, Rio de Janeiro, Brasil

\section{RESUMO}

A interferência colonial nos casamentos dos índios representa um capítulo importante da história colonial brasileira, pois modificou a estrutura e a dinâmica das sociedades nativas e abriu importantes caminhos para viabilizar os processos de conquista e colonização. $\mathrm{O}$ objetivo do artigo é analisar alguns aspectos deste problema, explorando especialmente dois momentos da política colonial: a imposição do casamento monogâmico cristáo, inaugurado durante o regime das missóes, e os incentivos aos casamentos mistos entre índios e "brancos", iniciado oficialmente com o Diretório pombalino.

Palavras-chave: índios; casamentos indígenas; casamentos mistos.

\section{Indigenous Peoples Marriages, Mixed Marriages, and Politics in Portuguese America: Friendship, Negotiation, Capitulation and Social Assimilation}

\begin{abstract}
Colonial interference on the marriages of indigenous peoples represents an important chapter in Brazilian colonial history, for it has modified the structure and dynamics of native societies, and enabled the emergence of important ways to make the processes of conquest and colonization viable. The objective of this article is to analyze some aspects of this problem, exploring two particular moments of the colonial politics: the imposition of Christian monogamous marriage, enacted during the mission regime, and the incentives for mixed marriages between Indians and 'whites,' which were officially initiated with the Pombaline Directory.
\end{abstract}

Keywords: indigenous peoples; indigenous peoples weddings; mixed marriages. 


\section{Matrimonios indígenas, matrimonios mixtos y política en la América portuguesa: amistad, negociación, capitulación y asimilación social}

\section{RESUMEN}

La interferencia colonial en los matrimonios de los indios representa un capítulo importante de la historia colonial brasileña, pues modificó la estructura y la dinámica de las sociedades nativas y abrió importantes caminos para viabilizar los procesos de conquista y colonización. El objetivo de este artículo es analizar algunos aspectos de este problema, explorando especialmente dos momentos de la política colonial: la imposición del matrimonio cristiano monógamo, inaugurada durante los regímenes de las misiones, y los incentivos a los matrimonios mixtos entre indios y "blancos", iniciados oficialmente con el Directorio Pombalino. Palabras clave: indios; matrimonios indígenas; matrimonios mixtos.

As representaçóes que cronistas, viajantes e missionários do período colonial fizeram dos índios encontrados na costa brasileira e de suas sociedades não foram unívocas. Mas prevaleceu a percepção de que se tratavam de povos que viviam em estado natural, sublinhando-se ora o idílico ora o bestial de seus costumes e modos de viver. Os primeiros jesuítas que chegaram ao Brasil identificaram nos índios o homem regido exclusivamente pela lei natural, vendo neles inicialmente a inocência bíblica anterior ao pecado original. Também acreditaram que eram homens e mulheres inteiramente disponíveis aos ensinamentos cristấos, i.e., páginas em branco nas quais se podia imprimir, sem dificuldade e resistência, o conjunto completo e não corrompido da moral e dos valores da Igreja. ${ }^{1}$ Décadas depois, o capuchinho Claude d'Abbeville salientou a mesma pureza entre os índios do Maranháo. Considerando que o pudor foi apenas descoberto por Adão e Eva depois que comeram o fruto do bem e do mal, sublinhou que a nudez refletia a inocência do povo, derivada do fato de desconhecerem o pecado original: "Como é que os Tupinambás herdando a culpa de Adão e seus pecados, não herdaram também a sua vergonha, efeito do pecado, como aconteceu à todas as naçóes do mundo?”. ${ }^{2}$

Não foram poucas, todavia, as dificuldades enfrentadas pelos missionários no processo de evangelização. Eduardo Viveiros de Castro dissecou o cerne das dificuldades e angústias

${ }^{1}$ EISENBERG, José. As missóes jesuiticas e o pensamento politico moderno. Belo Horizonte: Editora da UFMG, 2000, p. 101.

2 D’ABBEVIlle, Claudio. História da Missão dos padres capuchinhos na ilha do Maranhão e suas circunvizinhanças. São Luiz: Typ. do Frias, 1874, p. 315. Disponível em: <http://www2.senado.leg.br/bdsf/ handle/id/221724>. Sobre a visão de d'Abbeville segundo a qual os índios desconheciam o pecado original, acrescentou Afonso Arinos: "Explicaçấo que parece cheirar bastante a heresia." Cf. FRANCO, Afonso Arinos de. O indio brasileiro e a Revolução Francesa. 3. ed. Rio de Janeiro: Topbooks, s/d, p. 62. 
vividas pelos jesuítas, sublinhando que os índios mostravam-se "exasperadamente" difíceis de converter. ${ }^{3}$ De acordo com padre Antônio Vieira, os índios simplesmente eram inconstantes e não fixavam nada do que lhes era pregado e ensinado: “(...) a gente destas terras é a mais bruta, a mais ingrata, a mais inconstante, a mais avessa, mais trabalhosa de ensinar de quantas há no mundo." “ A conclusão de que os índios eram inconstantes na nova fé e religiấo repousava na propaladíssima ideia de que não tinham uma verdadeira religião e, apesar disso, resistiam à conversão unicamente movidos por seus "maus costumes". Mas, como argumentou Viveiros de Castro, os "maus costumes" dos tupinambás representavam "sua verdadeira religião, e (...) sua inconstância era o resultado da adesão profunda a um conjunto de crenças de pleno direito religiosas". 5 Em razão da "inconstância", dos "maus costumes" e da "brutalidade", os índios foram reclassificados como povos decaídos e manchados pelos pecado adâmico. Pior ainda, como estiveram apartados dos ensinamentos cristãos e alheios aos seus benefícios por muito mais tempo que os europeus, sua corrupção e decadência também se mostrava maior. Sinal da gravidade desse problema era, de acordo com padre Simão de Vasconcelos, a lastimável situação de que até mesmo as leis naturais foram praticamente esquecidas e extintas entre eles. ${ }^{6}$

Antropólogos, historiadores e ensaístas revisaram aspectos fundamentais da visão europeia original sobre o mundo ameríndio, reconhecendo que a sociedade tupinambá não era desregrada como fazem crer os relatos coloniais, que insistentemente sublinham a ausência de leis, de organização política e de religião entre eles. No campo da organização familiar, prevalecia entre os tupinambás o casamento entre primos cruzados ou o enlace da mulher com seu tio materno. Este poderia dispensar o casamento com a sobrinha, mas devia ser consultado acerca do assunto e o noivo passava, depois das núpcias, a assisti-lo no plano simbólico, da guerra e econômico (caça, pesca, limpeza das roças, construção de casa etc.). ${ }^{7}$ Além disso, aquilo que a moral cristã taxou de luxúria e libertinagem feminina era, da perspectiva indígena, hospitalidade.

\footnotetext{
${ }^{3}$ CASTRO, Eduardo Viveiros de. O mármore e a murta: sobre a inconstância da alma selvagem. In: CASTRO, Eduardo Viveiros de. A inconstância da alma selvagem e outros ensaios. São Paulo: Cosac Naify, 2002, p. 183-264, p. 185.

${ }^{4}$ VIEIRA, Antônio. Sermão do Espírito Santo. Portal Domínio Público. Disponível em: <http://www. dominiopublico.gov.br/pesquisa/DetalheObraForm.do?select_action=\&co_obra=16396>. Acesso em: 30 jan. 2018.

${ }^{5}$ CASTRO, Eduardo Viveiros de. O mármore e a murta: sobre a inconstância da alma selvagem. In: CASTRO, Eduardo Viveiros de. A inconstância da alma selvagem e outros ensaios. Sáo Paulo: Cosac Naify, 2002, p. 183-264, p. 192.

${ }^{6}$ RAMINELLI, Ronald. Eva tupinambá. In: PRIORI, Mary del (Org.). História das mulheres no Brasil. 8. ed. São Paulo: Contexto, 2006, p. 42

${ }^{7}$ MÉTRAUX, Alfred. The Tubinamba. In: STEWARD, Julian H. (Ed.). Handbook of South American Indians. Vol 1: The marginal tribes. Washington: Governanment Printing office, 1946, p. 119-126, p. 111. Biblioteca Digital Curt Nimuendajú. Disponível em: <http://etnolinguistica.wdfiles.com/local--files/hsai\%3Avol3p95-133/ vol3p95-133_tupinamba.pdf>. Acesso em: 10 jul. 2014.
} 
A alteridade ameríndia foi pouco compreendida e aceita pelos agentes coloniais, que terminaram classificando os costumes e as normas indígenas como desvios e corrupçôes das leis naturais e prova cabal da decadência e inferioridade deles em relação ao Ocidente cristão. Ao longo do tempo, conhecidos constructos sobre a amoralidade e/ou imoralidade ameríndia foram sendo renovados e reproduzidos. No século XVIII, por exemplo, escreveu padre Joáo Daniel: "Pelos costumes e teor de vida dos índios do rio máximo Amazonas, se pode já conhecer sua lei: é a de Epicuro, e dos ateus, que só reconhecem, e adoram os seus apetites, a sua vontade, e o seu ventre (...). Só tratam de comer e beber; no demais vida de brutos." As representaçôes coloniais sobre a moral sexual e a organização familiar indígena também justificaram a ativa intervenção política e religiosa sobre suas organizaçôes sociais. O objetivo do presente artigo é analisar algumas dimensóes desse processo intervencionista, explorando especialmente dois aspectos do problema: a imposição do casamento cristáo durante o regime das missóes e os incentivos aos casamentos mistos entre índios e "brancos" ao longo da vigência do Diretório pombalino.

\section{Casamentos indígenas e projeto missionário: o ponto de vista inaciano}

A família e a moral sexual da sociedade tupinambá foram objetos de atenta curiosidade e observaçấo. Gabriel Soares de Souza concluiu que os tupinambás eram um povo adepto da lascívia extrema: "São os Tupinambás tão luxuriosos que não há pecado de luxúria que não cometam (....". ' Jean de Léry e Claude d'Abbeville, ao contrário, sublinharam a temperança nativa, este último postulando existir mais modéstia e recato na nudez da mulher ameríndia do que em suas congêneres europeias, que abusavam de roupas cheias de artifícios e seduçôes..$^{10}$ Neste campo, contudo, a tendência mais forte foi a de sublinhar a poligamia, o desregramento, a sensualidade e a luxúria das mulheres "gentias". Vale citar o que disse delas padre José de Anchieta, assegurando que andavam nuas, não sabiam recusar as investidas sexuais dos europeus e, pior ainda, tinham por honra deitar-se com eles. Por isso mesmo, os procuravam de moto próprio com liberdade e frequência. ${ }^{11}$ Nascia, com essas narrativas, o que Ronald Raminelli chamou de Eva Tupinambá, i.e., a tradução da mulher nativa re-

\footnotetext{
${ }^{8}$ DANIEL, João. Tesouro descoberto no máximo rio Amazonas. Rio de Janeiro: Contraponto, 2004, p. 321, v. 1. ${ }^{9}$ SOUZA, Gabriel Soares de. Tratado descriptivo do Brasil em 1587. São Paulo: Companhia Editora Nacional, 1988, p. 376. Disponível em: <http://www.brasiliana.com.br/brasiliana/colecao/obras/9/tratado-descritivodo-brasil-em-1587>.

${ }^{10}$ LERY, Jean de. Viagem à terra do Brasil. Belo Horizonte: Itatiaia/São Paulo: Ed. da USP, 1980, p. 121. D’ABBEVILlE, Claudio. História da Missáo dos padres capuchinhos na ilha do Maranhão e suas circunvizinhanças. São Luiz: Typ. do Frias, 1874, p. 316. Disponível em: <http://www2.senado.leg.br/bdsf/ handle/id/221724>.

${ }^{11}$ FREYRE, Gilberto. Casa-Grande \& Senzala. 50. ed. São Paulo: Global, 2005, p. 161.
} 
alizada pelo campo normativo do colonizador. ${ }^{12}$ Uma mulher frequentemente acusada por missionários e cronistas de ser a fonte dos pecados e descaminhos dos homens e imortalizada em Casa-Grande \& Senzala como a responsável pelo ambiente "priápico" que supostamente grassava no Brasil dos primeiros contatos interétnicos. ${ }^{13}$

Pelo menos desde as reformas gregorianas, o controle sobre a sexualidade e o casamento foi um dos elementos fundamentais utilizados pela Igreja para ampliar e assegurar seu poder. Para isso, passou-se a realizar um controle mais rígido sobre os matrimônios, suprimindo-os para os padres e impondo aos leigos a benção e vigilância da Igreja. ${ }^{14} \mathrm{O}$ Concílio de Trento reforçou os princípios da monogamia e da indissolubilidade do matrimônio sacramentado. Desse processo, ainda saíram empoderados os jesuítas e sua condição de missionários militantes da Contrarreforma no Novo Mundo. Convém sublinhar que o encontro entre indígenas e europeus e de suas distintas moralidades sexuais e familiares foi um enorme desafio para a Igreja. Gilberto Freyre resumiu a questão: "O ambiente em que começou a vida brasileira foi de quase intoxicação sexual. O europeu saltava em terra escorregando em índia nua; os próprios padres da Companhia precisavam descer com cuidado, senão atolavam o pé na carne."15

A nudez e a liberdade sexual da mulher indígena efetivamente desnorteou alguns missionários. Padre Antônio da Rocha não escondia seu sofrimento. Dizia padecer diariamente de estímulos poderosíssimos, por estar incessantemente exposto à "luxúria" das mulheres nativas. ${ }^{16}$ Apesar das dificuldades, foi obra missionária, especialmente da Companhia de Jesus, cuidar do policiamento dos costumes da sociedade colonial em formação, interferindo na vida social, familiar e sexual de colonos e de indígenas. Em relação aos índios, a intervenção teve início com a chegada dos primeiros jesuítas, em 1549, por meio da crescente imposição da monogamia e do casamento cristão entre eles.

As fontes mais ricas sobre as relaçôes de parentesco entre os tupinambás são aquelas que foram produzidas pelos missionários. Interessados na evangelizaçáo dos índios, dedicaram-se à observação dos casamentos e das relaçóes familiares entre eles. A poligamia é assunto destacado na missiva inaciana e foi alvo de observação e estudo tanto dos jesuítas quanto de missionários pertencentes a outras ordens religiosas, que também vieram para o Brasil catequizar os índios. Em razão de ser o matrimônio monogâmico um dos sacramentos do catolicismo, a poligamia impedia a conversão e o batismo dos adultos, comprometendo seriamente o sucesso da obra missionária. Pode-se mesmo afirmar que superar a poligamia

\footnotetext{
${ }^{12}$ RAMINELLI, Ronald. Eva tupinambá, op. cit.

${ }^{13}$ FREYRE, Gilberto. Casa-Grande \& Senzala, op. cit., p. 169

${ }^{14}$ VAINFAS, Ronaldo. Casamento, amor e desejo no Ocidente cristão. 2. ed. São Paulo: Ática, 1992. p. 32. VAINFAS, Ronaldo. Trópico dos pecados: moral, sexualidade e Inquisição no Brasil Colonial. Rio de Janeiro: Campus, 1989.

${ }^{15}$ FREYRE, Gilberto. Casa-Grande \& Senzala, op. cit., p. 161

${ }^{16}$ RAMINELLI, Ronald. Eva tupinambá, op. cit., p. 26
} 
dos índios se tornou uma verdadeira obsessão dos missionários dedicados à evangelização.

A chave para entender o debate entre teólogos e missionários sobre o casamento ameríndio é o tema do casamento natural, como acertadamente salientou Charlotte Castelnau-L'Estoile. ${ }^{17} \mathrm{Na}$ cristandade do Antigo Regime o casamento e a família eram percebidos simultaneamente como fatos naturais e como instituiçóes civis e religiosas. ${ }^{18}$ Diante desse contexto, tratava-se de verificar se prevalecia entre os índios algum tipo de matrimônio regido pelas leis naturais, que basicamente significava o compromisso do casal viver uma vida comum e ter filhos. ${ }^{19}$ Em caso afirmativo, o segundo passo seria consagrar o casamento natural, transformando-o em matrimônio cristão.

Entre os inacianos, um dos que mais se dedicou à observação dos relacionamentos familiares dos nativos foi padre José de Anchieta, que procurou identificar a existência do casamento natural entre as múltiplas unióes indígenas por meio da identificação da uxor vera, i.e., da esposa verdadeira. Para isso, dedicou-se a observar a vida conjugal dos tupinambás e escreveu um texto importante sobre esse assunto. ${ }^{20}$ Verificou, em primeiro lugar, uma grande plasticidade e movimento nos relacionamentos matrimoniais deles - que se faziam e desfaziam-se com frequência, sem causar ofensas entre homens, mulheres e suas famílias. Na multiplicidade de unióes que homens e mulheres indígenas estabeleciam durante sua vida, queria descobrir a uxor vera e, graças a ela, identificar qual matrimônio era o mais "verdadeiro" e "legítimo", consagrando-o posteriormente por meio do sacramento cristão.

O método de Anchieta para avaliar as relaçôes familiares entre os tupinambás foi, em terminologia atual, etnográfico e linguístico, observando seus costumes e atentando-se para o uso dos termos indígenas para se referir aos diferentes membros da família. Seguindo este procedimento, verificou que os homens nominavam de temirecô as filhas e as irmás concedidas em casamento a um homem. Era por meio dessa entrega que as unióes (casamentos) eram seladas entre "Tamoios e Temiminós do Rio de Janeiro e do Espírito Santo, os Tupis de S. Vicente, os Tupinambás da Bahia e, finalmente, todos da costa e sertão do Brasil, dizendo leva esta para tua mulher (...)" ${ }^{21}$

\footnotetext{
${ }^{17}$ CASTELNAU-L'ESTOILE, Charlotte. Le mariage des infièles au XVI ${ }^{e}$ siècle: doutes missionnaires et autorité pontificale. Merfrim, v. 121, n. 1, p. 95-121, 2009, p. 101. CASTELNAU-L'ESTOILE, Charlotte. Interaçôes missionárias e matrimônios de índios em zonas de fronteiras (Maranhão, início do século XVII). Tempo, v. 19, n. 35, p. 65-82, jul./dez. 2013, p. 78. DOI: 10.5533/TEM-1980-542X-2013173505.

${ }^{18}$ HESPANHA, António Manuel. Direito luso-brasileiro no Antigo Regime. Florianópolis: Fundação Boiteux, 2005, p. 150.

${ }^{19}$ CASTELNAU-L'ESTOILE, Charlotte. Interaçóes missionárias e matrimônios de índios em zonas de fronteiras (Maranhão, início do século XVII), op. cit., p. 76.

${ }^{20}$ ANCHIETA, José de. Informação dos casamentos dos índios do Brasil. Revista Trimensal de Historia e Geographia ou Jornal do Instituto Historico e Geographico Brasileiro, t. VIII, p. 254-262. Rio de Janeiro: Typographia de João Ignacio da Silva, 1846 [2. ed., 1867], p. 258. Biblioteca Digital Curt Nimuendaju. Disponível em: <http://biblio.etnolinguistica.org/anchieta_1846_casamentos>. Acesso em: 15 mai. 2015.

${ }^{21}$ Ibidem, p. 258.
} 
Mas Anchieta ficou confuso e intrigado. Os índios chamavam de temirecô as suas diferentes mulheres (esposas): "com esse nome tem diversas em diferentes aldeias, e todas no mesmo foro que aquelas que têm consigo mais de assento em sua própria aldeia." ${ }^{22}$ Também chamavam de temirecô as mulheres que cativavam em guerra e que tomavam por esposa; por fim, eram chamadas de temirecô igualmente as mulheres que se uniam (amancebavam) aos portugueses. Desse ponto de vista, o termo temirecô era insuficiente para identificar a uxor vera. Por isso, Anchieta passou a buscar uma temirecô etê, já que etê podia ser traduzido por legítimo/legítima. ${ }^{23} \mathrm{Em}$ sua investigação, contudo, descobriu que "etê" não se aplicava às relaçôes de parentesco. Também percebeu que, por influência e insistência dos missionários, alguns índios passaram a designar algumas mulheres de temirecôetê para indicar a mais querida e estimada, mas não a "legítima" ou "verdadeira".

Utilizando o mesmo método, observou que as palavras xeremirecô ou xeraicig (a mãe dos meus filhos) e xemêna ou xemembira rûba (o pai dos meus filhos) tampouco designavam, respectivamente, a uxor vera e o maritus vero. ${ }^{24} \mathrm{~A}$ conclusão de padre Anchieta foi a de que inexistia um casamento natural entre os tupinambás. Como ele mesmo argumentou: "Os índios do Brasil parece que nunca tem ânimo de se obrigar, nem o marido à mulher, nem a mulher ao marido, quando se casam: e por isso a mulher nunca se agasta porque o marido tome outra ou outras (...)." ${ }^{25}$ Faltavam às uniôes ameríndias um verdadeiro "ânimo marital”26 - i.e., uma inclinaçáo para ter filhos em uma uniáo duradoura, baseada em obrigaçôes recíprocas de afeto, cuidado e respeito. Isso foi enfatizado por Anchieta. Com todas as mulheres, assinalou, os homens se juntavam com o mesmo ânimo e com nenhuma delas o "ânimo" indicava um compromisso que pudesse ser interpretado como um "casamento natural". Além disso, homens e mulheres não davam muitas demonstraçóes de "ciúmes" nas ocorrências de relaçóes extraconjugais e isso representava mais uma prova de que não se tinham por maridos e esposas verdadeiros. ${ }^{27}$

$\mathrm{Na}$ Companhia de Jesus, terminou preponderando a conviç̧ão acerca da inexistência de casamento natural entre os tupinambás. ${ }^{28}$ Isso gerou consequências importantes para a prática evangélica dos inacianos, pois puderam casar os índios de modo mais rápido e fácil, sem se preocupar em identificar a existência de alguma uniáo natural legítima anterior. Inicialmente, houve uma certa tendência de os padres identificarem a primeira união como a mais verdadeira, sacramentando-a por meio do matrimônio cristáo. Em outros casos, contudo, os padres tomaram como mais prudente legitimar pelo sacramento cristão a união que estava em voga, por ser mais do gosto e da aceitação dos próprios nubentes. Mas, como notou

\footnotetext{
22 Ibidem, p. 257.

${ }^{23}$ Ibidem, p. 258-259.

${ }^{24}$ Ibidem, p. 259.

${ }^{25}$ Ibidem, p. 254.

${ }^{26}$ Ibidem, p. 261.

${ }^{27}$ Ibidem, p. 255.

${ }^{28}$ CASTELNAU-L'ESTOILE, Charlotte. Interações missionárias e matrimônios de índios em zonas de fronteiras (Maranhão, início do século XVII), op. cit., p. 78.
} 
Anchieta, foram inclusive sacramentadas unióes cujas esposas foram dadas em casamento às vésperas do batismo do noivo, o que implicava que todas as demais fossem deixadas, inclusive a que estava mais em voga no momento. ${ }^{29}$

A convicção acerca da ausência de casamento natural entre os tupinambás não foi, todavia, uma unanimidade no mundo cristáo. Baseado na experiência da França Equinocial, o capuchinho francês Yves d'Evreux, que viveu entre os potiguares do Maranhão por dois anos, chegou a um ponto de vista diametralmente distinto. ${ }^{30}$ De acordo com Charlotte Castelnau-L'Estoile, ele destacou a conexão entre guerra e casamento, demonstrando que existia uma relaçáo de reciprocidade entre genros e sogros, pois os genros tinham que atendê-los no plano material e simbólico. Observou ainda que eram principalmente os grandes chefes e guerreiros ou filhos deles que tinham muitas esposas. Diante das evidências que recolheu, d'Evreux concluiu que entre os tupinambás existiam casamentos naturais, porque suas unióes se baseavam em leis naturais de obrigação recíproca. ${ }^{31}$

\section{Entre a negociação e a capitulação: o ponto de vista tupinambá}

O combate à poligamia dos índios foi trabalho pastoral intenso e contínuo dos jesuítas no Brasil e figurava entre as cláusulas e exigências que os missionários impunham aos índios para acertar a definitiva proteção, descimento e reduçáo deles em aldeias no mundo colonial. $\mathrm{Na}$ capitania do Espírito Santo, por exemplo, a aliança entre Vasco Fernandes Coutinho (primeiro donatário) e o chefe temiminó Maracaiá-Guaçu foi mediada pelos jesuítas, que exigiram posteriormente o batismo e o casamento cristão do grande chefe indígena.

Convém situar historicamente o contexto em que ocorreu a aliança entre Maracaiá-Guaçu e Vasco Fernandes Coutinho. Entre a chegada dos primeiros colonos na costa do Espírito Santo, em 1535, e a guerra ofensiva de Mem de Sá contra os índios da região, os relatos sobre o processo de conquista fazem menção a uma intensa e prolongada resistência armada dos índios, que combateram os portugueses sem dar-lhes trégua. As guerras luso-indígenas somente começaram a ser lentamente e parcialmente controladas a partir de 1555 , i.e., vinte anos depois do desembarque dos primeiros colonos. Para isso, foi fundamental o reforço na segurança local conseguida por meio da aliança que o donatário selou com o grande chefe temiminó Maracaiá-Guaçu (ou Maracajaguaçu ou ainda Maracayá-Guaçu), o Gato Grande (ou Gato Bravo). ${ }^{32}$

\footnotetext{
${ }^{29}$ ANCHIETA, José de. Informação dos casamentos dos índios do Brasil, op. cit., p. 261.

${ }^{30}$ D’EVREUX, Yves. Viagem ao Norte do Brasil feita nos anos de 1613 a 1614. Maranhão: Typ. do Frias, 1874. Disponível em: <https://catalog.hathitrust.org/Record/100366175>.

${ }^{31}$ CASTELNAU-L'ESTOILE, Charlotte. Interaçôes missionárias e matrimônios de índios em zonas de fronteiras (Maranhão, início do século XVII), op. cit., p. 73 e 78.

${ }^{32}$ OLIVEIRA, José Teixeira de. História do Estado do Espírito Santo. 3. ed. Vitória: APEES, 2008, p. 87.
} 
A aliança entre Vasco Fernandes e Maracaiá-Guaçu apenas foi possível porque no Rio de Janeiro os tupinambás estavam em guerra entre si, divididos e comendo-se uns aos outros, segundo o relato do jesuíta Simão de Vasconcelos. ${ }^{33}$ Padre Luís da Grã percebeu que os temiminós estavam em pior circunstância na guerra que travavam contra os tamoios e intermediou o acordo entre o donatário do Espírito Santo e o chefe temiminó. Assim, pouco depois, Maracaiá-Guaçu migrou para o Espírito Santo, trazendo consigo numerosa parentela que foi aldeada na regiáo. ${ }^{34} \mathrm{~A}$ importância dessa aliança para a segurança dos colonos pode ser auferida na preocupaçáo do donatário em agradar o chefe Maracaiá-Guaçu, concedendo-lhe terras e tratando-o com as formalidades prescritas e reservadas às pessoas de maior condição social. Padre Francisco Pires deixou testemunho detalhado sobre isso quando narrou o enterramento do filho de Maracaiá-Guaçu no Espírito Santo. Morto pela epidemia de varíola que varreu a regiāo, vitimando grande número de índios livres e escravos, o filho de Maracaiá-Guaçu recebeu uma cerimônia de enterramento conduzida com "grande pompa e solenidade". 35

Os episódios enleados na aliança entre Maracaiá-Guaçu e o primeiro donatário do Espírito Santo demonstram que a geopolítica portuguesa sabia tirar vantagens das guerras de vingança dos tupinambás, incentivando-as e orientando-as para seus próprios propósitos. Por outro lado, os índios sempre procuravam atender seus próprios interesses nas alianças que faziam com os cristãos. Os temiminós tornaram-se aliados dos portugueses no Espírito Santo, lutando ao lado deles contra outros índios e povos indígenas da região, porque, em troca, receberam terras para formar novas aldeias, onde estariam mais defesos contra os ataques que sofriam dos tamoios.

A aliança entre índios e cristãos tinha custos para os indígenas e não apenas econômicos e militares. Implicava aceitar e realizar, mais cedo ou mais tarde, mudanças importantes na organização social, política e religiosa de suas comunidades. As transformaçôes culturais negociadas, mas também exigidas dos grupos que aceitavam a aliança e o aldeamento junto aos portugueses, ficam particularmente claras nas celebraçóes que sucederam ao enterramento do filho de Maracaiá-Guaçu. Assim, durante a celebração do dia do Espírito Santo, Maracaiá-Guaçu e sua mulher foram batizados e casados e, nesta ocasiáo, Vasco Fernandes Coutinho deu ao chefe indígena grande festa. Para demonstrar seu apreço e consideração, fez questão de que ele recebesse seu próprio nome, sua esposa o nome de sua mãe e seus filhos os nomes de seus próprios filhos. Desde então, Maracaiá-Guaçu, o Gato Grande, ficou também conhecido como Vasco Fernandes, o Gato. ${ }^{36}$

\footnotetext{
${ }^{33}$ ALMEIDA, Maria Regina Celestino. Metamorfoses indígenas: identidade e cultura nas aldeias coloniais do Rio de Janeiro. Rio de Janeiro: Arquivo Nacional, 2003, p. 45. OLIVEIRA, José Teixeira de. História do Estado do Espírito Santo, op. cit., p. 87.

${ }^{34}$ ALMEIDA, Maria Regina Celestino. Metamorfoses indígenas: identidade e cultura nas aldeias coloniais do Rio de Janeiro, op. cit., p. 87.

35 TRASLADO de alguns capítulos de cartas do Padre Francisco Pires, que hão vindo do Espírito Santo. In: NAVARRO, Azpilcueta et al. Cartas Avulsas - 1550-1568. Belo Horizonte: Itatiaia/São Paulo: Edusp, 1988 , p. 220-223, p. 221, v. 2.

${ }^{36}$ Ibidem, p. 222.
} 
O acordo selado entre o chefe temiminó e o donatário do Espírito Santo impôs à Maracaiá-Guaçu o batismo e o casamento cristão, que eram, entâo, exigências que vinham do campo missionário jesuítico. Pela documentação existente não é possível determinar se Maracaiá-Guaçu casou-se e batizou-se de bom grado e efetivamente abraçando a nova religião; ou se aceitou os dois sacramentos apenas para cumprir exigências do momento e garantir mais plenamente a proteçáo que pretendia para si e seu povo ao se aldear na capitania do Espírito Santo. Apesar das incertezas, não restam dúvidas de que o batismo, o casamento cristão, o abandono da poligamia e a aceitação da indissolubilidade matrimonial eram expectativas missionárias impostas aos índios ao longo do processo de descimento e aldeamento deles no mundo colonial. O batismo demarcava, além disso, a nova condição e identidade de indivíduos e comunidades aldeadas. Fazia nascer o "índio cristão" e "vassalo" da Coroa portuguesa.

Nas fontes coloniais, a poligamia aparece especialmente associada aos grandes chefes e guerreiros e alguns deles chegaram a ter trinta mulheres. ${ }^{37}$ Todavia, mais de uma união ou casamento não simultâneo ao longo da vida de um indivíduo representava uma regra mais comum ou ampla. Afinal, homens e mulheres podiam se casar mais de uma vez, desfazendo-se de casamentos anteriores cujas partes não mais se interessavam por manter. Em relação à imposição da indissolubilidade matrimonial, a documentação atesta a dificuldade de os missionários implantarem essa norma entre os indígenas, pois continuaram desfazendo-se de certas unióes para contrair outras, mesmo depois de formalmente casados à moda cristã. Padre José Monteiro de Noronha deu testemunho disso nas narrativas que fez sobre suas visitas pastorais às aldeia dos rios Xingu, Tapajós e Amazonas, durante a década de 1750. Explicou e descreveu os métodos utilizados pelos missionários para desfazer os casamentos indígenas consagrados pela Igreja: o padre convocava os índios à igreja, publicamente segurava as mãos unidas do casal e "(...) tomando a Estola desatava as mãos dos casados, persuadindo aos índios que assim ficava dissolvido o vínculo do matrimônio que eles contraíram com o nexo da mesma Estola". ${ }^{38}$

O caso da estola desfazendo o matrimônio, narrado com "lágrimas de sangue" por padre Noronha,$^{39}$ atesta uma dimensão cada vez mais sublinhada por historiadores e antropólogos em suas investigaçôes: a conversão não foi uma via de mão única, em que os indígenas foram sumariamente "aculturados" e destituídos de sua cultura e indianidade, sem interferir, influir ou protagonizar qualquer papel de relevo no processo histórico-social. Ao contrário, os índios impuseram limites à ação dos missionários. Negociaram e protagonizaram escolhas e, com ou sem lágrimas de sangue, exigiram e/ou induziram que também os missionários

\footnotetext{
${ }^{37}$ MÉTRAUX, Alfred. The Tubinamba, op. cit., p. 112

${ }^{38}$ AHU.ACL.CU.013, cx. 44, D. 4033. Apud RENDEIRO NETO, Manoel. Casar, civilizar, colonizar: mulheres indígenas e a política de matrimônios mistos na Capitania de São José do rio Negro (1755-1779). Monografia (História) — Departamento de História, Universidade de Brasília, 2017, p. 45.

${ }^{39}$ Ibidem, p. 45.
} 
reajustassem suas crenças e condutas no forjamento da sociedade colonial, historicamente intercultural, intersubjetiva e interétnica em suas relaçóes, representaçóes e instituiçóes. ${ }^{40}$

Apesar das adaptaçóes e transformaçóes culturais e religiosas que também ocorriam no campo missionário, a exigência do casamento cristão tridentino visava liquidar, simultaneamente, com a poligamia dos grandes chefes e com a dissolução dos casamentos indígenas que grassavam entre homens e mulheres, impondo a monogamia e a indissolubilidade matrimonial e provocando a médio e longo prazo modificaçôes profundas na sociedade tupinambá. Dentre tais mudanças, Charlotte de Castelnau-L'Estoile salienta o empobrecimento material e simbólico provocado pela repressão à poligamia. Afinal, o poder político e econômico de grandes chefes e de suas aldeias e parentelas estava bastante associado à capacidade de terem muitas mulheres, vários filhos e de conseguir muitos genros, consolidando redes de trocas materiais e militares por meio dos matrimônios. ${ }^{41}$

Modificações aparentemente mais sutis merecem ser também destacadas, pois podiam transformar estruturas normativas mais profundas da sociedade tupinambá. $\mathrm{O}$ desenvolvimento e o desfrute da sexualidade entre os ameríndios náo estavam restringidos aos enlaces matrimoniais. Mas o casamento, o acesso a uma mulher fértil e à possibilidade de formar descendência geralmente acontecia para o homem por volta dos 25 anos, quando conseguia demonstrar ser um guerreiro valoroso e capaz de matar seus inimigos no campo de batalha e/ou no terreiro da aldeia nos rituais antropofágicos. De acordo com Manuela Carneiro da Cunha, o verdadeiro casamento do homem tupinambá só acontecia depois de consumada a primeira vingança: todo "filho era filho de um matador, e as mulheres recusavam-se a quem não houvesse matado". ${ }^{42}$ Nos aldeamentos, todavia, a estratégia jesuíta foi a de antecipar o casamento dos jovens por volta dos 17 anos. ${ }^{43}$ A medida foi adotada e aplicada segundo a velha concepçáo que vigorava na Igreja europeia, que considerava o matrimônio como necessário à procriação da humanidade, mas também como o mais eficaz remédio à concupiscência dos fiéis. ${ }^{44}$ Tal fórmula, contudo, atropelava normas e valores caros aos tupinambás, permitindo que homens sem a prerrogativa de bom guerreiro tivesse acesso ao casamento e ainda enfraquecia a autoridade de pais e tios na organização de suas respectivas parentelas e aldeias.

Em resumo, ao impor a indissolubilidade matrimonial, proibir a poligamia e instituir novas regras para autorizar o matrimônio e a procriação, o casamento cristáo exigido pelos mis-

\footnotetext{
${ }^{40}$ Entre outros, cf. MONTERO, Paula. Índios e missionários no Brasil: para uma teoria da mediação cultural. In: MONTERO, Paula (Org.). Deus na aldeia. Missionários, índios e mediação cultural. São Paulo: Globo, 2006, p. 31-66.

${ }^{41}$ CASTELNAU-L'ESTOILE, Charlotte. Interaçóes missionárias e matrimônios de índios em zonas de fronteiras (Maranhão, início do século XVII), op. cit.

${ }^{42}$ CUNHA, Manuela Carneiro da. Cultura com aspas. Sáo Paulo: Cosac Naify, 2009, p. 82.

${ }^{43}$ BACCI, Massimo Livi. Los estragos de la conquista. Quebranto y declive de los indios de America. Barcelona: Crítica, 2006.

44 PIMENTEL. Helen Ulhôa. A ambiguidade da moral colonial: casamento, sexualidade, normas e transgressóes. Univ. FACE, v. 4, n 1/2, p. 29-63, jan./dez. 2007, p. 34.
} 
sionários afetou as normas tradicionais da sociedade nativa e, ao fim e ao cabo, os próprios índios estabeleceram uma clara correlação entre casamento cristão, dominação colonial e capitulação frente aos interesses e poderes da sociedade conquistadora. É isso, pelo menos, que conclui Castelnau-L'Estoile ao analisar as perspectivas indígenas que aparecem na narrativa de Claude d'Abbeville, que viveu seis meses entre os índios do Maranhão, em 1612.45 Explorando atentamente a voz do chefe potiguar Momboré Ouassou (ou Momboré Uaçau) que aparece na narrativa de d'Abbeville, a autora demonstrou que o chefe potiguar interpretou a imposição do casamento cristão pelos missionários como a antessala da definitiva capitulação e escravização:

Vi o estabelecimento dos Perós [i.e., dos portugueses] em Pernambuco e Potyu, e o seu princípio foi como o vosso [i.e., dos franceses] agora. No principio os Perós só queriam negociar, e não morar aí: dormiam então à vontade com as raparigas, o que os nossos companheiros de Pernambuco e do Potyu reputavam grande honra. Depois disseram ser-lhes preciso aí morar, que necessitavam construir Fortalezas (...). Depois fizeram entender que não podiam ter assim as filhas deles, que Deus somente lhes permitia possuí-las por meio do casamento, que não podiam casar-se com elas, senão batizadas, e que para isso era necessário um Padre. Vieram os Padres, plantaram uma Cruz, começaram a instruí-los e depois foram batizados. Depois fizeram ver que tanto eles como os Padres precisavam de escravos para servi-los e trabalhar para eles (...). Não satisfeitos com os escravos aprisionados na guerra, quiseram também seus filhos, e finalmente cativaram toda a naçáo, e com tal tirania e crueldade a trataram sempre, que a maior parte dos que escaparam, viram-se obrigados, como nós, a deixar o país. Assim aconteceu com os franceses. Quando viestes aqui pela primeira vez foi simplesmente para negociar conosco, como os Perós não achastes dificuldades de tomardes nossas filhas, e nós nos jugávamos felizes quando elas tinham um filho vosso. (...) Depois da chegada dos Padres, plantaste a Cruz, como os Perós (...) e como eles ainda dizeis náo poderdes possuir nossas filhas senáo em casamento, e depois de batizadas. A princípio como os Perós não quisestes escravos, agora pedis e quereis como eles. ${ }^{46}$

Pesquisas e estudos recentes confirmam o caráter fluido das relaçôes matrimoniais entre os tupinambás e frisam a importância das alianças sociais e militares seladas entre os indígenas por meio do casamento. Para Manuela Carneiro da Cunha, por exemplo, a sociedade tupinambá não tinha "linhagens propriamente ditas" e tampouco "regras positivas de casamento". ${ }^{47}$ Apesar disso, era sobre o tripé guerra, vingança antropofágica e casamento que os tupinambás assentavam as bases de sua organização social. Neste contexto, a monogamia e a indissolubilidade matrimonial exigida pelos missionários quebravam alguns dos principais elos de colaboraçâo existentes na socie-

45 CASTELNAU-L'ESTOILE, Charlotte. Interaçóes missionárias e matrimônios de índios em zonas de fronteiras (Maranhão, início do século XVII), op. cit., p. 72.

46 D’ABBEVILle, Claudio. História da Missão dos padres capuchinhos na ilha do Maranhão e suas circunvizinhanças, op. cit., p. 171-172.

${ }^{47}$ CUNHA, Manuela Carneiro da. Cultura com aspas, op. cit., p. 82. 
dade multicomunitária tupinambá. Além disso, esse tipo de intervenção na organização familiar indígena tornou-se uma política de longa duração no Brasil, pois perdurou nos séculos seguintes em razão da prevalência da Igreja e dos valores católicos na sociedade colonial e pós-colonial brasileira.

\section{Casamentos mistos: política colonial e política indígena}

As uniôes e os matrimônios mistos foram comuns e estiveram presentes nas relaçôes interétnicas desde os primeiros encontros e contatos entre índios e não índios no Brasil. Mas índios e portugueses valoravam e instrumentalizavam de modo diverso os casamentos mistos. Os tupinambás, por exemplo, incorporaram os primeiros europeus à sociedade nativa segundo seus próprios interesses, respeitando a geopolítica de suas alianças de guerra e de matrimônio. Darcy Ribeiro nomeia de "cunhadismo" o costume e o modo de os tupinambás acolherem estranhos recém-chegados em suas terras. $\mathrm{O}$ processo era simples, direto e consistia "em lhes dar uma moça indígena como esposa. Assim que ele a assumisse, estabelecia, automaticamente, mil laços que o aparentavam com todos os membros do grupo". ${ }^{48}$ Muito diferente era o valor das unióes com indígenas para os primeiros conquistadores. ${ }^{49}$

Entre os primeiros europeus que chegaram à costa do Brasil, a historiografia salienta que o casamento com mulheres indígenas representou a mais segura e promissora porta de entrada para aceder-se à sociedade tupinambá e garantir a própria vida. Posteriormente, tais uniôes permitiram a definitiva conquista dos índios e a colonização da terra. As mais conhecidas e famosas uniôes interétnicas - e que geraram grande descendência de mamelucos que serviram de base à colonização portuguesa - aconteceram em Pernambuco, Bahia e São Vicente. Em Pernambuco, o cunhado de Duarte Coelho uniu-se com uma das filhas do grande chefe potiguar Arcoverde; em São Vicente, Joáo Ramalho selou sua aliança militar com o chefe Tibiriçá, casando-se com sua filha Bartira; na Bahia, Diogo Álvares, também conhecido como Caramuru, viveu entre os tupinambás, teve muitas mulheres indígenas e tornou-se o chefe de extensa linhagem de mamelucos. Não é demais sublinhar que os primeiros conquistadores se casavam ao modo indígena e, por isso mesmo, podiam ter várias esposas se fossem considerados grandes guerreiros e chefes. João Ramalho é um caso exemplar. A crônica jesuítica informa que o estilo de vida dele e de seus filhos era em tudo (ou quase em tudo) semelhante aos dos nativos: nudez, poligamia e participação ativa nas guerras e festas antropofágicas. Bartira, todavia, foi considerada pelos genealogistas a primeira mulher indígena de João Ramalho. Com a chegada dos jesuítas na regiáo, ela foi batizada e recebeu o nome de Isabel Dias..$^{50}$

\footnotetext{
${ }^{48}$ RIBEIRO, Darcy. O povo brasileiro. A formação e o sentido do Brasil. 2. ed. São Paulo: Companhia das Letras, 1995 , p. 81.

${ }^{49}$ METCALF, Alida C. Family and Frontier in Colonial Brazil. Santana de Parnaíba 1580-1822. Austin: University of Texas Press, 2005.

${ }^{50}$ METCALF, Alida C. Go-Betweens and the Colonization of Brazil: 1500-1600. Austin: University of Texas
} 
Duzentos anos depois da chegada dos primeiros missionários no Brasil, uma segunda intervençáo de grande porte foi realizada na vida familiar dos índios aldeados no perímetro colonial, graças aos incentivos oficiais aos casamentos mistos entre índios e "brancos", propostos pelas reformas do secretário de estado Sebastiáo José de Carvalho e Melo, posteriormente conhecido como Marquês de Pombal. Embora os matrimônios e as unióes entre índios e portugueses fosse um fenômeno antigo no Brasil, é importante notar que a partir das reformas pombalinas os casamentos mistos se transformaram em uma política oficial do governo colonial, adquirindo novo significado político e social. As reformas pombalinas se deram no século XVIII, a partir da década de 1750, e tinham como objetivo precípuo assimilar os indígenas à sociedade e à população colonial, assegurando honras e benefícios econômicos e políticos aos contraentes e aos descendentes de matrimônio com indígenas. A meta era literalmente destruir os índios como grupos étnicos e políticos diferenciados dentro do contexto colonial, pelo "suave" caminho dos casamentos mistos e de outras políticas adicionais. Ao fim e ao cabo, tratava-se de absorvê-los à população colonial e à sociedade envolvente, por meio da miscigenação biológica e da homogeneização linguística e cultural. A lei de 4 de abril de 1755 é o marco mais contundente do início dessa política. Ofereceu um conjunto de garantias e benefícios aos contraentes de casamentos com indígenas e seus descendentes, conforme ilustra o seguinte trecho da lei:

EU EL REI Faço saber aos que este Meu Alvará de Lei virem, que considerando o quanto convém, que os Meus Reais domínios da América se povoem, e que para este fim pôde concorrer muito a comunicação com os Índios, por meio de casamentos: Sou Servido declarar, que os Meus Vassalos deste Reino, e da América, que casarem com as Índias dela, não ficam com infâmia alguma, antes se farão dignos da Minha Real atenção, e que nas terras, em que se estabelecerem, serão preferidos para aqueles lugares, e ocupações, que couberem na graduação das suas pessoas, e que seus filhos, e descendentes seráo hábeis, e capazes de qualquer emprego, honra, ou Dignidade, sem que necessitem de dispensa alguma, em razão destas alianças, em que seráo também compreendidas as que já se acharem feitas antes desta Minha declaração: E outrossim proíbo, que os ditos Meus Vassalos casados com as Índias, ou seus descendentes, sejam tratados com o nome de Caboucolos, ou outro semelhante, que possa ser injurioso (..... ${ }^{51}$

No campo da política metropolitana portuguesa, os índios eram tidos como povos inferiores em termos civilizacional — pois considerados gente "bárbara", "rústica", "ignorante" —, e tratados no âmbito do direito penal como "miseráveis". 52 De acordo com Serafim Leite, uma 
boa medida da inferioridade dos indígenas aparece na Política Indiana do jurista Juan Solórzano Pereira, em que figura a ideia de que "a seis índios não se dá mais fé que uma testemunha idônea". No Brasil, o resultado prático disso foi que raramente os portugueses eram punidos pelos crimes praticados contra os índios, pois, na avaliação de padre Manoel da Nóbrega, eram necessários dois ou três testemunhos de homens brancos para que isso acontecesse. ${ }^{53}$

Em resumo, os índios eram tratados como inferiores aos brancos e aos portugueses. Considerando esse contexto histórico-cultural, a lei de 4 de abril era uma grande inovação, criando um verdadeiro desafio à ordem classificatória das pessoas no mundo colonial. Até entáo, as hierarquias sociais do Antigo Regime na metrópole e nas colônias estavam fortemente baseadas na concepção de "qualidade" atribuídas às pessoas, famílias e grupos. ${ }^{54}$ Contudo, a lei propunha novos parâmetros para o desenvolvimento das relaçóes interétnicas, estimulando o casamento misto - e, por conseguinte, a mistura de "sangue" entre índios e brancos —, e pondo em xeque-mate o paradigma da suposta "inferior qualidade" dos indígenas. Afinal, a lei de 4 de abril equiparava índios e portugueses em termos de distinção social, textualmente prometendo que os casamentos mistos e a mistura de sangue com indígenas náo seriam causa de "infâmia" ou de qualquer tipo de exclusão de privilégios para contraentes e descendentes.

Nos textos legais e recomendaçôes da época, o caráter assimilacionista do reformismo pombalino fica particularmente visível na frequente crítica ao modus operandi jesuítico. Nos termos do Diretório, por exemplo, os aforamentos das terras dos índios aos brancos era um meio de superar a "odiosa" separação entre índios e portugueses no mundo colonial, supostamente mantida e promovida pelos jesuítas nas aldeias que dirigiam. Sustentou-se o argumento de que a introdução de "brancos" nas terras dos índios significava um "suavíssimo" instrumento de "civilização", pois aumentaria o comércio e a comunicação entre índios e população colonial, facilitando inclusive os casamentos mistos. ${ }^{55} \mathrm{Na}$ mesma linha e com o mesmo objetivo de assimilar os índios, proibiu-se o uso das línguas nativas em aldeais, vilas e escolas, tornando obrigatório o uso da língua portuguesa. ${ }^{56}$ Os índios eram "povos conquistados" e nessa condiçâo deveriam obrigatoriamente falar a língua do príncipe. ${ }^{57}$

segunda metade do século XVIII. Lisboa: Comissão Nacional para as Comemorações dos Descobrimentos Portugueses, 2000.

${ }^{53}$ LEITE, Serafim. História da Companbia de Jesus no Brasil. São Paulo: CJS/Rio de Janeiro: Petrobrás, 2004, p. 245 , v. 2.

${ }^{54}$ Sobre o conceito de qualidade no mundo colonial, ver, entre outros: MCCAA, Robert. Calidad, classe, and marriage in colonial Mexico: the case of Parral, 1788-90. Hispanic American Review, v. 64, n. 3, p. 477501, 1984. RAPPAPORT, Joanne. Quién es mestizo? Decifrando la mezcla racial en El Nuevo Reino de Granada, siglos XVI y XVII. Varia História, v. 25, n. 41, p. 43-60, jan./jun. 2009.

${ }^{55}$ Diretório que se deve observar nas povoações dos índios do Pará e Maranhão, enquanto Sua Majestade não mandar ao contrário. In: ESPÍRITO SANTO. Livro tombo da vila de Nova Almeida. Vitória: Imprensa Oficial do Espírito Santo, 1945, \80, p. 78.

${ }^{56}$ Ibidem, $\$ 6^{\circ}$, p. 58.

${ }^{57}$ De acordo com o texto do Diretório: “Sempre foi máxima inalteravelmente praticada em todas as Naçôes 
Nas aldeias administradas pelos jesuítas se falava, efetivamente, línguas indígenas ou derivadas de idiomas indígenas. De acordo com Eduardo de Almeida Navarro, o tupi antigo foi falado até o final do século XVII, transformando-se, a partir de então, em língua geral, cujos ramos mais conhecidos são o nheengatu, falado no Norte, e a língua geral meridional irradiada a partir de São Vicente pelos paulistas e sua atividade bandeirante. A língua geral paulista atingiu Minas Gerais, Goiás, Mato Grosso e as capitanias do Sul. ${ }^{88}$ As missóes jesuíticas tiveram um papel central na consolidação da língua geral como idioma mais franco na América portuguesa. Os padres José de Anchieta e Luís Figueira foram fundamentais nesse processo. Gramaticalizaram o tupi antigo falado pelos índios da costa, tornando mais fácil a aprendizagem e difusão da chamada língua brasílica. Além disso, alguns aldeamentos, tornaram-se conhecidos dentro da Companhia de Jesus justamente porque eram considerados espaços privilegiados para os irmãos e padres aprenderem a "língua brasílica", i.e., o tupi antigo que, segundo José de Anchieta, era a língua mais falada na costa do Brasil.

No Diretório, a língua geral aparece definida como "invenção verdadeiramente abominável e diabólica” ( $\left.\$ 6^{\circ}\right)$ e, como tal, fazia parte do arsenal de críticas que o reformismo pombalino lançou contra os jesuítas e seus métodos de catequese e governança dos índios. Visando assimilar os índios à sociedade colonial, ainda se destacam no Diretório outras três medidas: a proibição de que os índios fossem chamados de "negros", pois isso impedia que eles fossem honrados e tratados "como se fossem Brancos" ( $\$ 10^{\circ}$ ); a orientação de que os diretores assegurassem que todos os índios tivessem nome e sobrenome português, para "os tratar e honrar como se fossem Brancos" ( $\$ 11^{\circ}$ ); e, bem mais radical do que as duas medidas anteriores, o incentivo aos casamentos mistos entre índios e "brancos", para extinguir "totalmente a odiosa e abominável distinção" ( $\$ 87^{\circ}$ ) entre eles. Para alcançar isso, o Diretório reassegurou o conteúdo da lei de 4 de abril de 1755, incentivando e regulamentando os casamentos entre índios e brancos e as honras e privilégios assegurados aos contraentes de casamentos com índios e seus descendentes $\left(\$ 88^{\circ}\right.$ a $₫ 91^{\circ}$ ), habilitando-os a todos os postos e honras compatíveis com suas graduaçôes. De acordo com o Diretório:

Para facilitar os ditos matrimônios empregarão os Diretores toda a eficácia de seu zelo em persuadir a todas as pessoas brancas que assistirem nas suas Povoaçôes que os índios tanto não são de inferior qualidade a respeito deles que dignando-se Sua Majestade os habilitar para todas aquelas honras competentes as graduações de seus postos, consequentemente ficam

que conquistaram novos domínios introduzir logo nos Povos conquistados o seu próprio idioma por ser indisputável que este é um dos meios mais eficazes para desterrar dos Povos Rústicos a barbaridade de seus antigos costumes: e ter mostrado a experiência que ao mesmo passo que se introduz neles o uso da língua do Príncipe que o conquistou se lhes rareia também o efeito e obediência, aliás a veneração e a obediência ao mesmo Príncipe." Cf. Idem.

${ }^{58}$ NAVARRO, Eduardo de Almeida. Curso de Lingua Geral (Nheengatu ou tupi moderno). A língua das origens da civilização amazônica. São Paulo: Paym Gráfica e Editora, 2011, p. 6. 
logrando os mesmos privilégios as pessoas que se casarem com os ditos índios, desterrando-se deste modo a prejudicialíssima imaginação dos moradores deste Estado que sempre reputavam por infâmias semelhantes matrimônios..$^{59}$

O texto do Diretório qualificou de "prejudicialíssima imaginação dos moradores" a convicção de que os índios eram de "inferior qualidade" e de que o casamento com eles fosse motivo de "infâmia". Assim, ao mesmo tempo em que negava a inferior qualidade dos índios e garantia honra e privilégios aos que contraíssem matrimônio com eles, reconhecia-se igualmente que os índios eram tidos e tratados de fato como inferiores no cotidiano da vida social colonial. Com as novas deliberaçóes, a expectativa de Pombal era absorver e assimilar os índios e seus descendentes na categoria de "brancos", por meio da mestiçagem biológica e cultural. Por isso mesmo, o Diretório mandava textualmente que os casamentos mistos dos índios em sua vilas e povoaçôes fossem feitos com cônjuges "brancos". Apesar disso, o que efetivamente vigorou foi o casamento de índios com "portugueses" e tais portugueses, embora fossem seguramente indivíduos livres, eram indistintamente "pardos" e "brancos".

Para compreender alguns efeitos dos casamentos mistos entre os indígenas, convém lembrar o que escreveu Hebe Mattos acerca da função social das cores atribuídas às pessoas durante o período colonial e imperial. De acordo com a autora, a cor “(...) não designava, preferencialmente, matizes de pigmentação ou níveis diferentes de mestiçagem, mas buscava definir lugares sociais, nos quais etnia e condição [civil] estavam indissociavelmente ligadas". ${ }^{60}$ Além disso, a historiografia tem demonstrado que os casamentos mistos dos indígenas que aconteciam na colônia eram mais variados do que o previsto em lei e não produziam, necessariamente, os efeitos esperados pela Coroa portuguesa. Em outras palavras, podiam engrossar o "pool reprodutivo" de "brancos", "pardos" ou "índios", pois dependiam, naturalmente, dos tipos de cônjuges envolvidos e das relaçóes de poder onde ocorriam as unióes e os casamentos interétnicos. ${ }^{61}$

O casamento de índios com africanos e afrodescendentes livres não produziu, por exemplo, uma nova geração de "brancos", tal como desejava a política assimilacionista de Pombal. Além disso, considerando-se os estigmas vinculados ao cativeiro e às cores do cativeiro, os casamentos mistos entre índios e portugueses pardos podiam lançar sobre a prole novos estigmas, além daqueles que já possuíam por sua consanguinidade ameríndia. ${ }^{62}$ Os casamentos mistos podiam

\footnotetext{
${ }^{59}$ Diretório que se deve observar nas povoações dos índios do Pará e Maranhão, enquanto Sua Majestade não mandar ao contrário, op. cit., $\$ 89$, p. 79.

${ }^{60}$ MATTOS, Hebe Maria. Das cores do silêncio. Rio de Janeiro: Nova Fronteira, 1998, p. 98.

${ }^{61}$ MOREIRA, Vânia Maria Losada. Territorialidade, casamentos mistos e política entre índios e portugueses. Revista Brasileira de História, São Paulo, v. 35, n. 70, jul./dez. 2015. Disponível em: <http://www.scielo.br/ scielo.php?script=sci_arttext\&pid=S0102-01882015000200017\&lng=pt\&nrm=iso\&tlng=pt\&ORIGINAL $\mathrm{LANG}=\mathrm{pt}>$. Acesso em: 10 out. 2015.

${ }^{62}$ RAMINELLI, Ronald. Impedimentos da cor. Mulatos no Brasil e em Portugal, c. 1640-1750. Varia, Belo Horizonte, v. 28, n. 48, p. 699-723, jul./dez. 2012. RAMINELLI, Ronald. Los limites del honor. Nobles y jerarquias de Brasil, Nueva España y Peru, siglos XVII y XVIII. Revista Complutense de Historia da América, v. 40, p. 54-68, 2014. VAINFAS, Ronaldo. Apresentação. In: VIANA, Larissa. O idioma da mestiçagem. As irmandades de pardos na América portuguesa. Campinas: Editora da Unicamp, 2007, p. 17-20.
} 
inclusive engrossar as fileiras dos escravizados, se homens indígenas contraíssem matrimônio com mulheres africanas ou afrodescendentes escravizadas. Vigorava no Brasil o princípio do partus sequitor ventrem, que impunha à prole a condição civil da mãe. ${ }^{63} \mathrm{~A}$ medida visava garantir o cativeiro e tal princípio foi mantido e respeitado pelas reformas de Pombal. Assim, depois da Lei das Liberdades de 1755, que proibiu todo e qualquer cativeiro de índios, a única forma legal de reduzir um índio a essa condição era ser filho de mãe escrava.

Também convém destacar que o casamento misto não desfazia, necessariamente, os laços de contraentes e descendentes com a comunidade indígena. A historiografia e a etno-história tem chamado a atenção para o tema da mestiçagem e sublinhado os processos de adaptação criativa encabeçado pelos índios diante de uma realidade social em profunda e rápida transformação, depois que foram implantados os sistemas coloniais no continente americano. Robin M. Wright frisou, por exemplo, o caráter adaptativo e político das novas identidades indígenas gestadas e consolidadas nos aldeamentos coloniais, onde, independentemente das especificidades das tradições e línguas particulares de seus diferentes membros, surge uma "indianidade" contra a ameaça de extinção imposta pela política colonial. ${ }^{64}$ Assim, pelo menos do ponto de vista dos índios, a miscigenação biológica não era um problema e tampouco razão suficiente para que eles deixassem de se ver como um povo específico e distinto em relação aos portugueses. Pesquisas documentais têm demonstrado que durante a vigência do Diretório os índios continuaram celebrando seus casamentos mistos a partir de costumes locais e interesses próprios, sem que isso significasse, necessariamente, o fim de seu sentimento de indianidade e de pertencimento a uma comunidade indígena. Nas vilas de índios da capitania do Espírito Santo, por exemplo, os nativos mitigaram a política assimilacionista dos aforamentos de terras e dos casamentos mistos, implementando uma política local de aforamento aberta somente aos homens que se casassem com índias da vila. Com isso, visava-se controlar o acesso dos não índios às terras coletivas, subordinando os aforamentos de terras e a entrada de novos moradores aos laços de lealdade e parentesco estabelecidos com os indígenas. ${ }^{65}$

Vale sublinhar que impor novas regras de casamento e uma nova moral sexual entre os índios não foi tarefa fácil. A resistência consciente ou inconsciente ameríndia às novas normas instituídas pela Igreja e pelo sistema colonial afloram em diferentes fontes históricas. Nas denúncias e nos processos inquisitoriais, por exemplo, a acusação de bigamia é um dos desvios de conduta que figura entre os mais corriqueiros cometidos por homens e mulheres classificados como índios. ${ }^{66}$ Por fim, convém também frisar que os incentivos aos casamentos mistos entre

${ }^{63}$ GOLDSCHMIDT, Eliana Rea. Casamentos mistos. Liberdade e escravidão em São Paulo colonial. São Paulo: Annablume, 2004, p. 116.

${ }^{64}$ WRIGHT, Robin M. Destruction, resistance, and transformation - Southern, Coastal, and Northern Brazil (1580-1890). In: SCHWARTZ, Stuart; SALOMON, Frank (Ed.). The Cambridge History of the Native People of the Americas. South America: Vol. III. New York: Cambridge University Press, 1999. Part. 2, p. 298. ${ }^{65}$ MOREIRA, Vânia Maria Losada. Territorialidade, casamentos mistos e política entre índios e portugueses, op. cit. ${ }^{66}$ CORRÊA, Luís Rafael Araújo. As idas e vindas de um indio mandingueiro nas malhas da Inquisiçâo: religiosidade, relaçóes interétnicas e mestiçagem no Espírito Santo e Rio de Janeiro (século XVIII). Tese (História) — Programa 
índios e não índios se tornou, ao lado do matrimônio cristão, outra política de longa duração no Brasil. A Carta Régia de 12 de maio de 1798 aboliu o Diretório, mas deu inequívoca continuidade à política de assimilação dos índios iniciada durante o consulado pombalino. Por um lado, prescreveu a "civilização" deles "(...) ao ponto de se confundirem as duas castas de índios e brancos em uma só de vassalos úteis ao estado e filhos da Igreja”. Por outro, concedeu novos incentivos aos casamentos mistos, garantindo aos brancos que se casassem com índias o privilégio de isenção de prestarem serviços públicos por certo número de anos, e aos soldados pagos o prêmio de receber a baixa no serviço militar. ${ }^{67}$ Mais ainda, o incentivo aos casamentos mistos reapareceu no período da Independência, sendo abertamente defendido por José Bonifácio de Andrade e Silva e, pouco depois, tornou-se política oficial do indigenismo do Brasil imperial. ${ }^{68}$

\section{Considerações finais}

A mestiçagem entre índios e não índios tem sido frequentemente interpretada como a via áurea que permitiu a assimilação social e cultural dos índios e a presença e participação deles na história nacional. Gilberto Freyre sublinhou o interesse sexual dos portugueses pelas indígenas e o clima priápico que prevaleceu nos tempos dos primeiros encontros interétnicos. Também destacou o protagonismo sexual da mulher nativa e seu interesse pelos ocidentais. ${ }^{69}$ Do encontro sexual e interétnico entre o europeu e a indígena formou-se uma sociedade "híbrida" no Brasil, em que a "mulher gentia" foi definida por Freyre como "a base física da família brasileira". ${ }^{70}$ Décadas depois, o argumento freyriano foi renovado e sublinhado por Darcy Ribeiro, que afirmou ser o indígena a "protocélula" do povo brasileiro. ${ }^{71}$

Caio Prado Júnior também deu grande destaque à mestiçagem quando tratou da "questáo indígena" durante a colônia. Para ele, no fim do período colonial o índio estava em franco processo de desaparecimento. Seu argumento era o de que o índio sobrevivente — isto é, os "restos da raça indígena" que não morreram devido às guerras, às chacinas, às epidemias e à exploração de sua força de trabalho — transitava da condição de indígena para uma outra,

\footnotetext{
de Pós-graduação em História, Universidade Federal Fluminense, Niterói, 2017, p. 207.

${ }^{67}$ Cópia da Carta Régia de 12 de maio de 1798 sobre a civilização dos índios, enviada a Antônio Peres da Silva Pontes, em 29 de agosto de 1798. In: OLIVEIRA, José Joaquim Machado de. Notas e apontamentos e notícias para a história da província do Espírito Santo. Revista do IHGB, Rio de Janeiro, t. XIX, n. 22, p. 161-335, 1856, p. 318-320.

${ }^{68}$ De acordo com Bonifácio: "Procurará com o andar do tempo, e nas aldeias já civilizadas, introduzir brancos e mulatos morigerados para misturar as raças, ligar os interesses recíprocos dos índios com a nossa gente, e fazer deles todos um só corpo da nação, mais forte, instruída e empreendedora (...)." Cf. SILVA, José Bonifácio de Andrada e. Apontamentos para a civilização dos índios bravos do Império do Brasil. In: CALDEIRA, Jorge (Org.). José Bonifácio de Andrada e Silva. São Paulo: Editora 34, 2002, p. 183-199, p. 198.

${ }^{69}$ FREYRE, Gilberto. Casa-Grande \& Senzala, op. cit., p. 161.

${ }^{70}$ Ibidem, p. 162.

${ }^{71}$ RIBEIRO, Darcy. As Américas e a civilização. Rio de Janeiro: Civilização Brasileira, 1970, p. 244
} 
definida como "massa geral da população", por meio da "miscigenação" e da "aculturaçấo". ${ }^{2}$ Em linha convergente, Maria Luiza Marcílio, que é uma referência importante na demografia histórica brasileira, escreveu: "Com a expulsão dos jesuítas do Brasil, que coincidiu com o lançamento das novas políticas de Pombal destinadas a estimular o crescimento da população por meio da mistura de raça, a população indígena ingressou num novo período de declínio e absorção." 73

Apesar dessas interpretaçóes dominantes, a homogeneização cultural e a criação de novas identidades políticas e sociais entre os índios merecem ser analisadas mais detidamente, pois foram fenômenos complexos, frequentemente demorados e não devem continuar sendo tratados como meros epifenômenos de casamentos e uniôes mistas ou da política assimilacionista de Pombal. Convém notar, por exemplo, que novas clivagens de "cor" e "sangue" passaram a impregnar práticas, discursos e modos de organizar e hierarquizar a sociedade colonial, distribuindo os descendentes de casamentos mistos em novas ordens discursivas e sociais. Assim, muitos descendentes de casamentos mistos passaram a ser classificados como "pardos" e "caboclos". Além disso, sólidas investigaçóes etnográficas têm demonstrado que os grupos étnicos e suas fronteiras não desaparecem necessariamente em virtude da mistura biológica e das trocas culturais. ${ }^{74} \mathrm{~A}$ experiência concreta de vários aldeamentos indígenas que foram alvo das reformas pombalinas apontam claramente para isso. Afinal, apesar da miscigenação e de uma clara política institucional visando a absorção dos indígenas à população colonial, índios aldeados e/ou vilados permaneceram como grupo étnico e social específico e diferenciado até o final do período colonial, chegando algumas dessas comunidades à história do tempo presente.

\section{Fontes}

ALVARÁ de 4 de abril de 1755. In: SILVA, Antônio Delgado da. Collecção da legislação portuguesa. Desde a última compilação das ordenaçôes. Legislação de 1750 a 1762. Lisboa: Typografia Maigrense, 1830.

ANCHIETA, José de. Informação dos casamentos dos índios do Brasil. Revista Trimensal de Historia e Geographia ou Jornal do Instituto Historico e Geographico Brasileiro, t. VIII, p. 254-262. Rio de Janeiro: Typographia de João Ignacio da Silva, 1846 [2. ed., 1867], p. 258. Biblioteca Digital Curt Nimuendaju. Disponível em: <http://biblio.etnolinguistica. org/anchieta_1846_casamentos>. Acesso em: 15 mai. 2015.

\footnotetext{
${ }_{72}$ PRADO JÚNIOR, Caio. Formação do Brasil contemporâneo. 11. ed. São Paulo: Brasiliense, 1971, p. 93. ${ }^{73}$ MARCÍlIO, Maria Luiza. A população do Brasil colonial. In: BETHELL, Leslie (Org.). História da América Latina: América Latina colonial. São Paulo: Edusp, 2009, p. 318, v. II.

${ }^{74}$ Cf. entre outros BARTH, Fredrik. O guru, o iniciador e outras variaçóes antropológicas. Rio de Janeiro: Contracapa, 2000, p. 35. OLIVEIRA, João Pacheco de (Org.). A viagem da volta. Etnicidade, política e reelaboração cultural no nordeste indígena. 2. ed. Rio de Janeiro: Contracapa, 2004.
} 
CÓPIA da Carta Régia de 12 de maio de 1798 sobre a civilização dos índios, enviada a Antônio Peres da Silva Pontes, em 29 de agosto de 1798. In: OLIVEIRA, José Joaquim Machado de. Notas e apontamentos e notícias para a história da província do Espírito Santo. Revista do IHGB, Rio de Janeiro, t. XIX, n. 22, p. 161-335, 1856, p. 318-320.

DANIEL, João. Tesouro descoberto no máximo rio Amazonas. Rio de Janeiro: Contraponto, 2004, v.1.

D’ABBEVILLE, Claudio. História da Missão dos padres capuchinhos na ilha do Maranhão e suas circunvizinhanças. São Luiz: Typ. do Frias, 1874, p. 315. Disponível em: <http:// www2.senado.leg.br/bdsf/item/id/221724>.

D’EVREUX, Yves. Viagem ao Norte do Brasil feita nos anos de 1613 a 1614. Maranhão: Typ. do Frias, 1874. Disponível em: <https://catalog.hathitrust.org/Record/100366175>.

DIRETÓRIO que se deve observar nas povoaçóes dos índios do Pará e Maranhão, enquanto Sua Majestade não mandar ao contrário. In: ESPÍRITO SANTO. Livro tombo da vila de Nova Almeida. Vitória: Imprensa Oficial do Espírito Santo, 1945.

LERY, Jean de. Viagem à terra do Brasil. Belo Horizonte: Itatiaia/São Paulo: Ed. da USP, 1980. SILVA, Antônio Delgado da. Collecção da legislação portuguesa. Desde a última compilação das ordenaçôes. Legislação de 1750 a 1762. Lisboa: Typografia Maigrense, 1830.

SILVA, José Bonifácio de Andrada e. Apontamentos para a civilização dos índios bravos do Império do Brasil. In: CALDEIRA, Jorge (Org). José Bonifácio de Andrada e Silva. São Paulo: Editora 34, 2002, p. 183-199.

SOUZA, Gabriel Soares de. Tratado descriptivo do Brasil em 1587. Sáo Paulo: Companhia Editora Nacional, 1988. Disponível em: <http://www.brasiliana.com.br/brasiliana/ colecao/obras/9/tratado-descritivo-do-brasil-em-1587>.

TRASLADO de alguns capítulos de cartas do Padre Francisco Pires, que hão vindo do Espírito Santo. In: NAVARRO, Azpilcueta et al. Cartas Avulsas - 1550-1568. Belo Horizonte: Itatiaia/Sáo Paulo: Edusp, 1988, p. 220-223.

VIEIRA, Antônio. Sermão do Espirito Santo. Portal Domínio Público. Disponível em: $<$ http://www.dominiopublico.gov.br/pesquisa/DetalheObraForm.do?select_action=\&co_ obra $=16396>$. Acesso em: 30 jan. 2018.

\section{Referências bibliográficas}

ALMEIDA, Maria Regina Celestino. Metamorfoses indigenas: identidade e cultura nas aldeias coloniais do Rio de Janeiro. Rio de Janeiro: Arquivo Nacional, 2003.

BACCI, Massimo Livi. Los estragos de la conquista. Quebranto y declive de los indios de America. Barcelona: Crítica, 2006. 
BARTH, Fredrik. O guru, o iniciador e outras variaçôes antropológicas. Rio de Janeiro: Contracapa, 2000.

CASTELNAU-L'ESTOILE, Charlotte. Le mariage des infièles au XVI ${ }^{\mathrm{e}}$ siècle: doutes missionnaires et autorité pontificale. Merfrim, v. 121, n. 1, p. 95-121, 2009.

. Interações missionárias e matrimônios de índios em zonas de fronteiras (Maranhão, início do século XVII). Tempo, v. 19, n. 35, p. 65-82, jul./dez. 2013. DOI: 10.5533/TEM1980-542X-2013173505.

CASTRO, Eduardo Viveiros de. A inconstância da alma selvagem e outros ensaios. São Paulo: Cosac Naify, 2002.

CORREAA, Luís Rafael Araújo. As idas e vindas de um indio mandingueiro nas malhas da Inquisição: religiosidade, relaçóes interétnicas e mestiçagem no Espírito Santo e Rio de Janeiro (século XVIII). Tese (História) — Programa de Pós-graduação em História, Universidade Federal Fluminense, Niterói, 2017.

CUNHA, Manuela Carneiro da. Cultura com aspas. São Paulo: Cosac Naify, 2009.

DOMINGUES, Ângela. Quando os indios eram vassalos: colonização e relaçóes de poder no Norte do Brasil, na segunda metade do século XVIII. Lisboa: Comissão Nacional para as Comemorações dos Descobrimentos Portugueses, 2000.

EISENBERG, José. As missóes jesuiticas e o pensamento politico moderno. Belo Horizonte: Editora da UFMG, 2000.

FRANCO, Afonso Arinos de. O indio brasileiro e a Revolução Francesa. 3. ed. Rio de Janeiro: Topbooks, s/d, p. 62.

FREYRE, Gilberto. Casa-Grande \& Senzala. 50. ed. São Paulo: Global, 2005.

GOLDSCHMIDT, Eliana Rea. Casamentos mistos. Liberdade e escravidão em São Paulo colonial. São Paulo: Annablume, 2004.

HESPANHA, António Manuel. Direito luso-brasileiro no Antigo Regime. Florianópolis: Fundação Boiteux, 2005.

LEITE, Serafim. História da Companhia de Jesus no Brasil. Sáo Paulo/Rio de Janeiro: CJS/ Petrobrás, 2004, v. 2.

MARCÍLIO, Maria Luiza. A população do Brasil colonial. In: BETHELL, Leslie (Org.). História da América Latina: América Latina colonial. São Paulo: Edusp, 2009, p. 318, v. II. MATTOS, Hebe Maria. Das cores do silêncio. Rio de Janeiro: Nova Fronteira, 1998.

MCCAA, Robert. Calidad, classe, and marriage in colonial Mexico: the case of Parral, 178890. Hispanic American Review, v. 64, n. 3, p. 477-501, 1984.

METCALF, Alida C. Family and Frontier in Colonial Brazil. Santana de Parnaíba 15801822. Austin: University of Texas Press, 2005a. 
. Go-Betweens and the Colonization of Brazil: 1500-1600. Austin: University of Texas Press, 2005b.

MÉTRAUX, Alfred. The Tubinamba. In: STEWARD, Julian H. (Ed.). Handbook of South American Indians. Vol 1: The marginal tribes. Washington: Governanment Printing office, 1946, p. 119-126, p. 111. Biblioteca Digital Curt Nimuendajú. Disponível em: <http:// etnolinguistica.wdfiles.com/local--files/hsai\%3Avol3p95-133/vol3p95-133_tupinamba. pdf $>$. Acesso em: 10 jul. 2014.

MONTERO, Paula (Org.). Deus na aldeia. Missionários, índios e mediação cultural. São Paulo: Globo, 2006.

MOREIRA, Vânia Maria Losada. Territorialidade, casamentos mistos e política entre índios e portugueses. Revista Brasileira de História, Sáo Paulo, v. 35, n. 70, jul./dez. 2015. Disponível em: <http://www.scielo.br/scielo.php?script=sci_arttext\&pid=S0102$01882015000200017 \& \operatorname{lng}=\mathrm{pt} \& \mathrm{nrm}=\mathrm{iso} \& \mathrm{t} \operatorname{lng}=\mathrm{pt} \& O R I G I N A L L A N G=\mathrm{pt}>$. Acesso em: 10 out. 2015.

NAVARRO, Eduardo de Almeida. Curso de Lingua Geral (Nheengatu ou tupi moderno). A língua das origens da civilização amazônica. São Paulo: Paym Gráfica e Editora, 2011.

OLIVEIRA, João Pacheco de (Org.). A viagem da volta. Etnicidade, política e reelaboração cultural no nordeste indígena. 2. ed. Rio de Janeiro: Contracapa, 2004.

OLIVEIRA, José Teixeira de. História do Estado do Espirito Santo. 3. ed. Vitória: APEES, 2008. PIMENTEL. Helen Ulhôa. A ambiguidade da moral colonial: casamento, sexualidade, normas e transgressóes. Univ. FACE, v. 4, n. 1/2, p. 29-63, jan./dez. 2007.

PRADO JÚNIOR, Caio. Formação do Brasil contemporâneo. 11. ed. São Paulo: Brasiliense, 1971. RAMINELLI, Ronald. Eva tupinambá. In: PRIORI, Mary del (Org.). História das Mulheres no Brasil. 8. ed. São Paulo: Contexto, 2006.

. Impedimentos da cor. Mulatos no Brasil e em Portugal, c. 1640-1750. Varia, Belo Horizonte, v. 28, n. 48, p. 699-723, jul./dez. 2012.

. Los limites del honor. Nobles y jerarquias de Brasil, Nueva España y Peru, siglos XVII y XVIII. Revista Complutense de Historia da América, v. 40, p. 54-68, 2014.

RAPPAPORT, Joanne. Quién es mestizo? Decifrando la mezcla racial en El Nuevo Reino de Granada, siglos XVI y XVII. Varia História, v. 25, n. 41, p. 43-60, jan./jun. 2009.

RENDEIRO NETO, Manoel. Casar, civilizar, colonizar: mulheres indigenas e a politica de matrimônios mistos na Capitania de São José do rio Negro (1755-1779). Monografia (História) — Departamento de História, Universidade de Brasília, 2017.

RIBEIRO, Darcy. As Américas e a civilizaçâo. Rio de Janeiro: Civilização Brasileira, 1970.

. O povo brasileiro. A formação e o sentido do Brasil. 2. ed. Sáo Paulo: Companhia das Letras, 1995. 
VAINFAS, Ronaldo. Trópico dos pecados: moral, sexualidade e Inquisição no Brasil Colonial. Rio de Janeiro: Campus, 1989.

. Casamento, amor e desejo no Ocidente cristão. 2. ed. São Paulo: Ática, 1992. . Apresentação. In: VIANA, Larissa. O idioma da mestiçagem. As irmandades de pardos na América portuguesa. Campinas: Editora da Unicamp, 2007, p. 17-20.

WRIGHT, Robin M. Destruction, resistance, and transformation - Southern, Coastal, and Northern Brazil (1580-1890). In: SCHWARTZ, Stuart; SALOMON, Frank (Ed.). The Cambridge History of the Native People of the Americas. South America: Vol. III. New York: Cambridge University Press, 1999. Part. 2. 